https://doi.org/10.18485/kud_kiaz.2019.ch5

\author{
Елдар Хасанов \\ Амбасадор Републике Азербејџан у Републици Србији
}

\title{
МУЛТИКУЛТУРАЛИЗАМ И ТОЛЕРАНТНИ НАЧИН ЖИВОТА У АЗЕРБЕЈЏАНУ
}

\begin{abstract}
SUMMARY
Multiculturalism is relevant not only for the region where Azerbaijan is located, but also for the whole world. Azerbaijan is a country of rich history and cultural heritage. It is no coincidence that 2016 was declared a year of multiculturalism in Azerbaijan. Multiculturalism in Azerbaijan is not a slogan, but rather acts in practice, where for many years representatives of different ethnic and religious communities, live in peace and harmony. As a result, the multicultural traditions that have evolved over the centuries have turned the way of life of the Azerbaijani people.
\end{abstract}

Key words: Multiculturalism, cultural heritage, world, ethnic community.

Културни центар Азербејџана није случајно изабрао тему „Мултикултурализам: искуство Азербејџана” за наш округли сто, јер је она актуелна не само за регион него и за цео свет. С друге стране, наша земља Азербејџан има богату традицију мултикултурализма. Година 2016. је проглашена годином мултикултурализма у Азербејџану. Другим речима, имамо шта да испричамо и да поделимо с вама. Охрабрујуће је и то што земље региона, као што су Румунија, Црна Гора и Србија, такође дају свој допринос процесу подстицања мултикултурализма у свету. 
Као што знате, већ је прошло више од две деценије откако се човечанство ослободило притиска конфронтације из времена хладног рата. Али без обзира на то, мора се признати да се наде у безбеднији светски поредак још увек нису оправдале, већ се, напротив, ситуација погоршала. Претњу нуклеарним уништењем цивилизације замениле су нове опасности и изазови, као што су тероризам и сепаратизам, национални, религијски и други облици екстремизма, регионални сукоби, финансијско-економске кризе, миграције и друго. Сви ти проблеми постојали су и раније, али сада, у условима глобализације, када је свет постао много више међусобно повезан и међусобно зависан, они су почели брзо да стичу универзални карактер, представљајући стварну претьу за регионалну и међународну безбедност.

У контексту горенаведених проблема, азербејџанска држава, полазећи од свог дугогодишњег искуства, верује да би подстицање мултикултурализма могло да послужи као одговор, ако не на све, онда на многе од наведених проблема, посебно у светлу проблема са којима се сусрела Европа због великог прилива миграната последњих година.

Најпре желим да подсетим да се под мултикултурализмом подразумева етничка, језичка, конфесионална разноврсност и разноврсност стилова живота неког друштва. Ако је раније та разноврсност проистицала, пре свега, из историјске хетерогености становништва држава, у послератним деценијама њен основни извор постала је имиграција. У том контексту мултикултурализам се појавио као потреба да се мигрантско становништво укључи у живот државе пријема.

Неопходно је истаћи да се последњих година снажан прилив миграната усмерио у Западну Европу после такозваног ,арапског пролећа” које је фактички разрушило стабилност у земљама Блиског истока. Рат у Сирији и Ираку, активност терористичких групација попут ДАИШ/ ИДИЛ (или Ал Каиде) такође су одиграли своју улогу. 
Али мигранти нису само Сиријци или Ирачани, већ и они који беже из Сомалије, Нигерије, Авганистана и тако даље. Мора се признати да тешка економска ситуација, заједно са другим факторима, такође представља извор миграција.

Знамо какав је однос према мигрантима у појединим земљама Европе. У многим развијеним земљама Запада нажалост је у порасту број присталица крајње националистичке идеологије и ултрадесничарских политичких партија, а расистички и шовинистички испади су учестали. Важно је знати да није искључено да ће они који се односе лоше према једној групи људи сутра циљати и на друге групе. Осим тога, мигранти нису само муслимани. У многим западним земљама живе мигранти из других земаља Источне Европе. И актуелни процеси могу негативно да утичу на вредности толеранције у свету и да доведу до хаоса.

У том смислу бих желео да подсетим на речи председника Илхама Алијева који је казао: „,У савременом свету мултикултурализам нема алтернативу. Јер апсолутна већина земаља света су многонационалне земље. Ако је мултикултурализам претрпео крах, шта онда може да буде његова алтернатива? И то је врло јасно. То су дискриминација, расизам, ксенофобија и антисемитизам."

Данас, желимо да са вама поделимо искуства мултикултурализма у Азербејџану. Наша земља се налази у области Јужног Кавказа. Азербејџан се налази управо на оном географском простору који је светски познати српски писац Милорад Павић изабрао за место радње свог познатог романа Хазарски речник, где је велики мајстор пре неколико деценија, када свет још није размишљао о неопходности дијалога цивилизација, доказао да мултикултурализам може да буде само богатство једне земље. Познато је да Павић није без разлога изабрао Кавказ за место радње Хазарског речника, пошто Кавказ, као и Балкан, има богату разноврсност култура и налази се на раскрсници Истока и Запада, Севера и Југа, хришћанства и ислама, разних цивилизација и култура. Мултикултура- 
лизам је она особеност наших региона чије претварање у наше богатство, а не у нашу несрећу, представља управо наше умеће, управо нашу мудрост.

С тим у вези морам да истакнем да је азербејџански мултикултурализам преплитање историје, традиције, вредности, социјалног понашања и навика, као и државне политике. Мултикултурализам у Азербејџану није парола, већ деловање у пракси, у којој током много година представници различитих етничких и религијских заједница живе у миру и хармонији. У нашој земљи се мултикултурализам током много векова претворио у начин живота нашег народа.

Многи од вас вероватно знају да је као резултат рата који је започела Јерменија крајем 1980-их и почетком 1990-их година било окупирано 20\% територије Азербејџана, а више од милион људи постали су избеглице и принудно расељена лица. Са тих територија Азербејџанци су у потпуности протерани. Наши религијски и културно-историјски споменици били су збрисани са лица земље или озбиљно оштећени. Али без обзира на то, јерменска црква, која се налази на централном и једном од најлепших места у Бакуу, остала је цела и нетакнута. У нашем карактеру није да подижемо руку на споменике других култура, на свети дом великога Бога, и никада на тај сукоб нисмо гледали као на етнички или религијски.

Држава Азербејџан снабдева бесплатном енергијом верске објекте свих конфесија које историјски постоје у Азербејџану. Само у Азербејџану можете видети да на једном месту мирно стоје и јеврејска синагога и џамија, као и католичка и православна црква. Оне се рестаурирају и одржавају на рачун државе. Од 2013. године азербејџанска држава снабдева бесплатним гасом објекте свих вероисповести у суседној Грузији, укључујући и јерменске цркве.

Ми као држава дајемо свој допринос развоју мултикултурализма у свету, како на регионалном, тако и на међународном нивоу. У Азербејџану је од 2014. године ак- 
тиван Међународни центар мултикултурализма у Бакуу. У земљи се одржава много догађаја на ту тему, о чему ће причати наши говорници.

На крају свог излагања желео бих да кажем да национализам, нетолеранција, дискриминација, као и подизање зидова, не представљају одговор на наше глобалне проблеме; пут до њиховог решења остварује се кроз дијалог, поштовање према другима и хуманост. То представља једини исправан пут, пут без алтернативе, који можемо да покажемо нашој деци ради мирне коегзистенције.

\section{РЕЗЮМЕ}

Мультикультурализм- актуален не только для региона, где находится Азербайджан, но и для всего мира. Азербайджан является страной с богататой историей и культурным наследием. И неслучайно, что 2016 год был объявлен в Азербайджане годом мультикультурализма. Мультикультурализм в Азербайджане не является лозунгом, а скорее действует на практике, где на протяжении многих лет представители различных этнических и религиозных общин, живут в мире и согласии. В результате, мультикультуральные традиции, складывающиеся на протяжении веков превратились в образ жизни азербайджанского народа.

Ключевые слова: Мультикультурализм, культурное наследие, мир, этническая община. 